\title{
Redaksioneel
}

\section{Die nuwe Nasionale Instituut vir Materiaalnavorsing}

Suid-Afrika word allerweë beny vir sy geweldige mineralerykdom, maar tensy dit ten volle tot voordeel van die land se tegnologiese vooruitgang benut word, sal ons nooit die status van 'n ontwikkelde moondheid bekom nie.

Tot onlangs het Suid-Afrika hom hoofsaaklik toegespits op mineraalekstraksie of mynboutegnologie en die uitvoer van ertse as sulks of in 'n half verwerkte vorm. Hierdie pogings het daartoe gelei dat ons op die gebied van diepmyntegnologie en raffineertegnieke 'n wêreldleier geword het.

As 'n ontwikkelende land kan ons egter nie langer bekostig om ons grondstowwe uit te voer en dan klaarvervaardigde goedere, gemaak uit die einste stowwe wat ons verskaf het, te koop teen drasties verhoogde pryse nie. Die tyd het aangebreek om ons eie goedere te vervaardig wat nie net die land se tegnologiese status sal verbeter nie, maar ook ons buitelandse valuta.

Materiaalwetenskap en materiaalingenieurswese vorm ' $n$ essensiële deel van hierdie ontwikkelingsproses. Om hierdie inisiatief op 'n nasionale grondslag te plaas, het die WNNR onlangs aanbeveel dat ' $\mathrm{n} \mathrm{Na-}$ sionale Instituut vir Materiaalnavorsing gestig word. Die regering het dit goedgekeur en die nuwe instituut het op 1 Januarie 1983 amptelik tot stand gekom.

As 'n outonome WNNR-instituut dra dit nou die primêre verantwoordelikheid om namens die WNNR navorsing in materiaalwetenskap en materiaalingenieurswese in Suid-Afrika te bevorder.

Die doelwitte van die Instituut kan as volg opgesom word:

- Om navorsings- en ontwikkelingsprojekte in die nasionale belang te onderneem en waar moontlik toekomstige behoeftes te identifiseer, byvoorbeeld om 'n gevorderde infrastruktuur van aktiewe navorsing te verskaf wat die werklike behoeftes van materiaaltegnologie sal ondersoek, om ' $n$ invoervervangingstegnologie te ontwikkel, om nuwe toepassings vir Suid-Afrikaanse grondstowwe te vind, soos $\mathrm{Cr}$, Mn, die Pt-groepmetale, $\mathrm{ZrO}_{2}$ en hul uitvoer te bevorder;

- om deur middel van navorsing en die lewering van gespesialiseerde dienste by te dra tot die ontwikkeling en ondersteuning van die nywerheid, byvoorbeeld deur die vestiging van 'n basis van deskundigheid om nuwe tegnieke vir materiaalprosessering te ontwikkel;

- om gespesialiseerde fasiliteite daar te stel, te beman en te bedryf, met ontwikkeling van die nodige deskundigheid, op die hoogste internasionale vlak en om in ' $n$ raadgewende kapasiteit op te tree om materiaalwetenskap en -ingenieurswese in SuidAfrika te bevorder;

- om met universiteite te skakel om samewerking op navorsingsprogramme, ontwikkeling van relevante leerplanne, ensovoorts te bevorder;

- om met buitelandse institute saam te werk deur kennis en wetenskaplikes uit te ruil en wetenskaplike bydraes tot internasionale programme te maak (wat alleenlik suksesvol deur aktiewe navorsers gedoen kan word wat 'n daadwerklike bydrae in ruil kan lewer);

- om aan die aktiwiteite van internasionale organisasies soos IUPAP*, IUPAC*, ensovoorts, deel te neem.

Die Instituut sal hom veral op metale, keramiek, glas, halfgeleiers, polimere en saamgestelde materiale toelê, asook op die hantering van 'n verskeidenheid spesifieke materiaalprobleme, soos korrosie, skuring, ensovoorts. 